\title{
LANGUAGE MILTON-MODEL ANALYSIS IN POLITICAL DISCOURSE
}

\author{
Kovalevska Anastasia \\ $\mathrm{PhD}$ in Philology \\ ORCID 0000-0002-1031-5546 \\ Odesa Regional Institute for Public Administration \\ of the National Academy for Public Administration \\ under the President of Ukraine \\ 22, Genuezka Str, Odesa, 65009, Ukraine \\ ana.kovalevskaya@gmail.com
}

The article is dedicated to the analysis of the verbal influence (also known as suggestion) realization phenomenon in political discourse, which is usually understood as a holistic combined image of the text (be it an advertisement slogan, a political program, a speech, or an interview) itself and the emotions of its recipient and addressee. and is aimed at a a political subject's (politics, political force, power) influencing a political object (audience, electorate, voter). The political discourse is studied from the standpoint of Psychology, Communicative Linguistics, Sociolinguistics, Speech Acts Theory, Advertisement Theory, PR / GR, Political Linguistics and other related sciences, but it is the involvement of such new methods of studying the linguistic and extralinguistic implementation of suggestion in political discourse, influence being its basic function, that emphasizes the relevance of the work, aimed at studying the manifestations of suggestion in political discourses with the help of NLP's Milton-model analysis. Contemporary political discourse as an array, which, given the specificity of its functioning in today's information society, is characterized by immanent suggestogenicity is the object of the research; while the essential linguistic features of political discourse as a tool for the realization of its programmed suggestibility are the subject.

The factual data of the research is represented by recorded media speeches, political advertisement, political programs and press conference speeches of the politicians heading the governments of Ukraine, USA, France, Spain, Italy, Canada, Germany (about 200 items of each class). The author involves the meta- and Milton-model analysis of the text having been researched and developed in the NLP paradigm in order to isolate the actual linguistic influential patterns (markers of language metamodeling processes, simple, complex and indirect inductions).

The linguistic algorithm of Milton-model analysis of political discourses having been researched and visually illustrated with relevant examples combines a complex scientific approach within such multisubstrate science as NLP, and thus it will allow not only to single out dominant strategies of constructing texts and mechanisms of these discourses, but also to highlight the ways to counteract their negative effect, as well as serve in the construction of appropriate planning decisions in the field of optimizing the effectiveness of political communication, emphasized the prospects of the research having been presented in the article, as well as its essential practical value.

Key words: language Milton-model, Neurolinguistic Programming, political discourse, political speech, political advertisement, influence, suggestion, Milton-model analysis, NLP, political communication, verbal markers of influence.

\section{Introduction}

The political discourse is a special one, and thus is separated from the other types of discourse on various grounds: structural and functional peculiarities (Serebrych, 2020: 101); personality / institution (Karasik, 2002: 208), social situational parameter (Shevchenko,

(C) Kovalevska A., 2020 
2005: 233 - 236), semiotic signs differentiation (Pocheptsov, 1999: 75 - 90), object of research (Sovremennye teorii diskursa, 2006: 27), but usually, it's defined as "a set of all speech acts, as well as the rules of public policy, which were formed in accordance with existing traditions and tested by experience" (Slavova, 2010: 67), because "the fields of politics are somehow mediated by discourse, reflected in the discourse, realized through discourse: they either become the subject of communication, or act as elements of a pragmatic context, including pragmatic presuppositions" (Sheygal : 24).

\section{Materials and research methods}

Within the paradigm of the political discourse, the scientists also elicit its agents and clients (figures who represent a certain type of discourse, and those who "initiate the appeal" (Semeniuk, 2010: 120), which, in our opinion, could be correlated with the management concepts of stakeholders and target audiences): the "players" who unfurl the action of the acquisition of power and its retention, the formation and impact on public consciousness, personified in a dichotomy of government vs. society (Semeniuk, 2010: $130-131$ ). The "function of the struggle for power, its seizure and its preservation" (Sheygal, 2004) is main function of any political discourse, and it is possible to interpret it as suggestive one, ie aimed at convincing the recipient or group of recipients of the correct position of a party or a politician, so that they have a reason to support them, and usually, the addressees are being convinced that this particular position is the only correct one, thus making sticking to any other an automatic mistake.

As per usual, political discourse is the research object of Communicative Linguistics, Socio- and Pragmalinguistics, Political Linguistics, Theory of Speech Acts and other related sciences, but to optimize the study of this phenomenon from the solely linguistic standpoint, we suggest to carry the analysis out with the help of Neurolinguistic Programming (NLP), since it is "an essential area of research and optimization of interpersonal interaction in almost the entire current discursive genres spectrum: medicine, advertising, politics, media, etc" (Kovalevska \& Kovalevska, 2020 : 185) which is a "a powerful scientific field that contains a detailed methodological apparatus and a system of practical techniques and technologies that can relate to the neurophysiological mechanisms of influence on the cognitive and psycho-emotional sphere of an individual" (Kovalevska \& Kovalevska, 2020 : 186). Language Milton-model, being one of its most important instruments, is aimed at analyzing the linguistic realization of suggestion, initializing the activity of the subconscious (which is characterized by increased semantic diffusion), describes the complex of linguistic and extralinguistic components of communicative suggestion, the features of the linguocultural information perception paradigm, and is focused on introducing the recipient to the downtime phase, when one's "attention is focused on the sensory sensitivity" (O'Connor \& Seymour, 1997: 143).

It is the involvement of such new methods of studying the linguistic and extralinguistic implementation of suggestion in political discourse, influence being its basic function, that emphasizes the relevance of the work, aimed at studying the manifestations of suggestion in political discourses with the help of NLP's Milton-model analysis. In order to achieve this aim, it is necessary to execute the following tasks: to characterize the language Milton-model as the newest tool for describing communicative suggestion; identify the main components of the Milton-model used in the contemporary political discourse; to analyze these components from the standpoint of the NLP's language Milton-model. Contemporary political discourse as an array, which, given the specificity of its functioning in today's information society, is characterized by immanent suggestogenicity is the object of the research; while the essential linguistic features of political discourse as a tool for the realization of its programmed suggestibility are the subject. The factual data of the research is represented by recorded media speeches, political advertisement, political programs and press conference speeches of the politicians heading the governments of Ukraine, USA, France, Spain, Italy, Canada, Germany (about 200 items of each class). 


\section{Discussion and results}

According to M. Erickson, the maximum value for the effectiveness of suggestive communication is achieved by a clearly defined sequence of actions aimed at ensuring that the perception of the message by the recipient was natural, which would allow its optimal effectiveness, because "when you try to persuade a person by suppressing them, it will cause a reaction of resistance" (Bandler \& Grinder, 1999 : 19), and this sequence usually consists of three consecutive stages.

The first stage of such potentially suggestive (hypnotic) communication is to establish the rhythm of communication, its synchronization with the behavior of the interlocutor, which, in turn, will force them to subconsciously synchronize their actions with the actions of the suggestor, and thus increase the effectiveness of potential influence.

At the second stage, the linguistic components of communication become of maximum importance, as it involves joining (assimilating one's linguistic behavior to the linguistic behavior of the suggester with his subsequent subconscious desire to adhere to this "synchronicity") and maintaining (maintaining this state to maximize influence) to achieve subconscious trust on the part of the interlocutor, and hence - to optimize the perception of the message.

Within the third stage, "the different etymology semantic diffusion phenomenon and forming the semantic-rhythmic-melodic continuity of speech due to the use of certain semantic and stylistic means acquires the highest level of importance" (Kovalevska, 2001 : 319), which allows free access of the suggestor to the subconscious of the suggestor. At each of these stages, certain linguistic and extralinguistic components are used, which determines the need to provide their characteristics.

Thus, the indicators of the language metamodel (Bandler \& Grinder, 1999; Kovalevska, 2001; Kovalevska, 2018; O’Connor \& Seymour, 1997) could be considered as the first component of the language Milton-model, noting that the Milton-model is a mirror functional reflection of the metamodel, that is, while the metamodel aims to explain and detail sentences with process markers used in them, the Milton model "is a way of forming sentences with a large number of omissions, distortions and generalizations" (O'Connor \& Seymour, $1997: 148)$.

The next component comprises of the simple inductions - actions and statements that "clearly direct the mental mechanisms of the listener in a fixed direction, not assuming or rather leveling the significance of their own interpretations of the situation" (Kovalevska, $2001: 318$ ), which are divided into:

1. Verbal synchronization - a stage of influence, which involves "achieving a state of trust on the part of the suggestion through the use of predicate characteristics of speech and adequate analog behavior" (Kovalevska, 2001 : 319), when in order to create the maximum naturalness effect, the suggestor, before moving on to the actual hypnotic inductions, uses a number of sensory-based statements, which allows to reduce the level of criticality in the perception of the latter, potentially influential statement (ie, "You can hear me now. And you can see as clear as the light of day, feel as surely as your own breathing, that I will fulfill all my promises").

2. Non-verbal synchronization is the suggestor's non-verbal adjustment to the suggestee, which usually causes the latter to feel a subconscious desire to trust and accept any message with much greater commitment (reflection technique), and is aimed achieving rapport.

3. Representative systems superposition is characterized by the use of all the suggestee's perception systems by utilizing the appropriate predicates within a single text, which leads to neurophysiological desynchronization of representative systems and, in turn, to the activation of trance states of consciousness (Kutuza, $2018: 314$ ) (eg, "You can see the sound of freedom", "Feel the bright colors of change", "You can feel that you have a completely different politician. Yes, we are changing", "Yes, I see that we were given a cold reception. But all this can be fixed"). 
4. Access to past trance states is an induction, which "occurs by actualizing the person's previously existing the emotional states (usually positive), resulting in the so-called automatic regression ..., ie renewal of the set of former emotions" (Kutuza, $2018: 314$ ) and is realized by appealing to past positive experiences (which is very often achieved by utilizing the language metamodel markers, e.g. "Let's return well-known politicians to power", "Everything used to be better", "Let's restore our country"). Although this inductor is usually aimed at actualizing the positive states, sometimes we registered the actualization of negative ones ("Do you want another 5 years of such a life?", "What did they lead the country to?", "End of the poverty era”).

5. Access to normal trance states is an induction associated with "creating mental relaxation through visual-auditory and verbal construction" (Kutuza, 2018 : 316), which, in the advertising message, may be associated with an explicitly demonstrated reaction of the mediator (usually positive), which leads to a certain identification of the recipient with him, that "in the practice of hypnosis is associated with techniques of infection or imitation" (Kutuza, 2018 : 316) (e.g. "It's cozy and calm in a country with honest government", "The most native, Odessa party", "Peace and quiet in your favorite country").

The next components of the language Milton-model is represented by the complex (developed) inductions which are the potentially suggestive complexes, that "are practically not realized by listeners / speakers, and their suggestive potentials are very significant" (Kovalevska, $2001: 322$ ), which include:

1. Lever inductions - a type of induction "based on physiological catalepting of the hands and forearms, which generates unusual physiological behavior as a stimulus to the predicted reaction and correlates with the relevance of nonverbal adjustment" (Kovalevska, $2001: 322)$.

2. Pattern disruption is an induction which signifies "finding ... a single element of repetitive behavior, which is then unexpectedly interrupted" (Bandler \&Grtinder, 1999 : 92), thus initializing "the psychological mechanism of unexpected behavior, the mismatch of the predicted reaction of the interlocutor with the "software package", concluded by the communicator, which corresponds to the last phase of speech generation" (Kovalevska, 2001 : 199), e.g. when a candidate whose general image is positioned as balanced, tolerant and intelligent unexpectedly starts using obscenities or vulgar lexis in his speech (eg, "Of course, I understand what you are talking about. Well, oh, so what now? I $f^{* * *}$ ed up, and I'll make it right", "Yes, I was wrong here. Haven't you ever been wrong? F*** you with your criticism!”, "I'm not your kid! I am the President! I'm not a sucker!”).

3. Overload is an induction "associated with the need for quick, instant response to seemingly easy tasks" (Kovalevska, 2001 : 324), the effectiveness of which is explained by the fact that, in its natural balance, of human consciousness is able to hold the number of units of information, which within NLP is called "Miller's magic number" and equals $7 \pm 2$ (Miller, 1998), and exaggeration of this limit can lead to the transfer of consciousness to the downtime phase, which also makes a person extremely susceptible to impact (eg, "Do you want higher salaries? Do you want higher pensions? Do you want lower rates? Do you want peace in the country? Do you want freedom? Do you want to change everything? Do you understand that our party is your only choice? Vote for us!"').

4. "Components of reality" induction which is based on "the formation of an ambiguous framework of what you do, .... through the stringing of situational descriptions one inside the other" (Kovalevska, $2001: 324)$, and in turn "overloads your conscious ability to follow which statement belongs to what" (Bandler \& Grinder, 1999 : 104) (e.g. "First we should take up the economy, but to take up the economy, we need to solve the issue of pension reform, but to solve the issue of pension reform, we need to fix the pension legislation, and to fix the pension legislation, we need to see what we have there in the Constitution. It's difficult").

4. N. Kutuza considers citation or reference to authority to be a hypnoinducer of a complex systaxic structure (Kutuza, 2018), and in our opinion, it should be seen as a complex inductions, because, firstly, it has an indisputable suggestive potential, since it's aimed at 
uncritical perception of the information presented in the message, and secondly, like other complex inductions, it is based on forming a semantically and perceptually diffuse message frame withing its recipient's perception, since precedent names are used not only to denote a particular person, situation, but also as a certain cultural sign, a symbol of certain features or events, gaining a certain emotional shade depending on the situation to which they relate (Nahimova, 2007 : 4) (eg, "Churchill also said that if you want peace-you must prepare for war", "As Taras Shevchenko wrote, Ukraine, having been robbed by evil people, will be woken up by them"). We also suggest to distinguish a so-called "precedent" citation as a separate kind of complex induction, when the author of the quoted information is not explicitly named, but the quoted text is a precedent one, ie clearly connected in the minds of the audience with a particular person / hero / situation (e.g. "All factories should belong to the workers", "Don't read newspapers before dinner", "The force doesn't work that way"), which also activates a semantically and perceptually diffuse frame of the message and connection with an unreal situation in the subconscious of the recipient.

5. Truisms are "banal" messages almost everyone will agree with, given that they are completely true, which, however, is completely subjective. We suggest to include this element into the paradigm of complex inductions of the language Milton-model, given that, first, they increase the level of the suggestee's subconscious trust in the suggestor, because they are perceived mostly as true, and secondly, "do not require special thought due to their obviousness and therefore fall immediately into the subconscious, bypassing the level of conscious processing" (Prisyazhniy), while a truism is almost never perceived as an influence, given the prevalence and well-knownness of these texts (eg, "A strong leader is a strong country", "The country is its people", "People can trust each other"). Researchers divide truisms into such subspecies: a) banal truth is well-known facts that are not usually potentially suggestive, but can be used to tune to the caller or its calibration (eg, "Ukraine is a great country", "We all live here", "Next year is 2021"); b) proverbs and sayings, which are usually perceived as positively as possible given their general knowledge, but given the fact that "proverbs are many and completely opposite in meaning, you can always choose the one that sets the desired framework of perception" (Liubymov) (cf. "Work is not a wolf, it will not escape into the woods" (meaning the case can be postponed) and "Without work you will not take the fish out of the pond" (meaning cases can not be postponed)); c) phrases that fully correspond to reality - in contrast to the two previous types, when the suggestor uses existing texts in the communication situation, this type describes truisms having been constructed point by point for a specific task, in order to "create an expression that would fully match the client's card and would not create any objections, but would set the right framework for perception" (Liubymov) (e.g. "Everyone can be wrong", "Everyone should understand what is happening in the country"); d) pseudo-truisms are phrases that look like truisms, starting with a reference to the general knowledge of a certain fact or the person / group of people who declares it, before the directly influential statement (eg, "There has been a lot of news recently that there will be a lot of dismissals in the Presidential Administration soon", "Many colleagues say we have to wait for the revolution. Let's see, let's see", "There is an opinion that it is necessary to reduce the number of deputies").

So-called indirect inductions are the last type of induction, elicited within the language Milton-model, and are aimed at actualization of the hidden, not verbally explicit commands to which they belong:

1. Analog marking stands for "suprasegmental accentuation of the message (tone, intonation, etc.) in combination with the actual paralinguistic selection (gesture, facial expression), which is used to enhance the (indirect) actual segments of the message" (Kovalevska, $2001: 328$ ).

2. Built-in commands are the hidden commands that level the imperative of direct command, since "imperativeness as a fundamental communicative feature" (Kravchenko \& Bondarenko, 2020 : 172), but retain its influence due to a complex of formal softening and naturalness of form (cf. "Vote for us!" and "You choose whether to vote for us"). 
3. Built-in questions correlate with induction built-in commands, their specificity being that "one's own question, aimed at obtaining certain information about the listener, is not asked directly, but is integrated into a larger structure, where the main accented part (usually the main sentence) distracts the listener from other semantic segments, freeing a really significant part of the analytical control of the interlocutor" (Kovalevska, 2001 : 329) (cf. "Who will you vote for?" and "I'm really curious who you voted for"). In the network this induction, constructions such as "do you know that...", "do you understand that...", which appeal to the general awareness of the recipient and "push them to consent, so as not to appear to be ignorant" (Kutuza, 2018 : 335) could also be utilized.

4. Negative commands are the inductions that contain negative particles "no" and "none", the phenomenon of perception of which is that, initially, the consciousness of the recipient perceives a key concept - ie the command without "no" "as a means to understand the sentence" (Bandler \& Grinder, 1999 : 290) (eg, "Who, if not us?", "When, how not now?"). However, the incorrect use of this induction can minimize or completely negate the initially positive effect of the message, because "messages that begin with objections, negative commands .... can be decoded as a call to action" (Kutuza, $2018: 337$ ), which can completely change the information vector of the message (eg, "We will not give the green a chance to pass!", "We will not allow devastation!").

5. Conversational postulates are "such formulations of questions that already give you the right reaction without a direct request for it" (Kovalevska, 2001 : 329), containing a hidden question, which the recipient subconsciously reconstructs in a scenario preprogrammed by the suggestor and gives him a certain expected response, not perceiving it as a command (eg, "Will you vote? The EU team wants you to make the right choice").

6. Ambiguities are "an important tool that can cause mild confusion and disorientation" (Bandler \& Grinder, 1999 : 290), which involves the use of elements of the language metamodel to create a diffuse, fuzzy interpretation of the message. Within this induction, the scientists separate following types: a) phonological ambiguities, "which are determined by the articulatory-acoustic similarity of speech units" (Kovalevska, 2001 : 330), thus creating a programmable unexpected effect in the perception of the recipient of the formally expected units (e.g. "War-no! Peace - da!" slogan creates an allusion between the sound of the English word "peace" and its complex with the word "yes" and the well-known obscene word in Ukrainian / Russian); b) semantic ambiguities, "which cause the need for subjective filling of semantic gaps of objective content" (Kovalevska, 2001 : 330) and are quite often expressed by homophones, homographs and homoforms, which allow multiple interpretations of the meaning of a message (for example, Vitali Klitschko's slogan " $U D A R$ " ("BLOW") simultaneously creates an associative link between his boxing career, and hence strength and endurance, and the name of his party "UDAR"); c) syntactic ambiguities, "realized through variable semantic connections between the elements of the message" (Kovalevska, 2001 : 330), which also create a plurality of meanings depending on the interpretation of the syntactic structure of the sentence (eg "Not win lose").

\section{Conclusions and prospects}

We believe that since the linguistic algorithm of Milton-model analysis of political discourses considered in our research combines a comprehensive scientific approach within such a multisubstrate science as NLP, it will allow not only to "unfurl" the dominant strategies used to construct texts within these discourses and deep mechanisms of their construction, but also - in the future - ways to counteract their negative effect, which will serve to deepen the relevant provisions of NLP and related areas of suggestive and psycholinguistics. On top of that, the prospects of utilizing the aforementioned analysis algorithm lies within the possible construction of appropriate planning decisions in the field of optimizing the effectiveness of political communication, which is one of the most important aspects of forming the information space and thus maximizes the prospects for further development in this scientific field, what emphasized the prospects of the research having been presented in the article, as well as its essential practical value. 


\section{REFERENCES}

Bandler \& Grinder, 1999 - Bandler R. \& Grinder D. (1999). Transformeyshn [Transformation]. Syktyvkar : Flinta, 296 p. [in Russian]

Karasik, 2002 - Karasik V. I. (2002). Jazykovoj krug: lichnosti, koncepty, diskurs [Language circle: personalities, concepts, discourse]. Volgograd: Peremena, 477 p. [in Russian]

Kovalevska, 2018 - Kovalevska A. V. Information Wars' Pathogenic Texts Neutralization Algorithm (2018). Notes on Ukrainian linguistics = Opera in linguistica ukrainiana. Vol. 25, pp. 227 - 239 [in English]

Kovalevska \& Kovalevska, 2020 - Kovalevska T., \& Kovalevska A. (2020). Utilizing the Neurolinguistic Programming Technologies in Foreign languages Teaching Practice in Ukrainian Universities. Arab World English Journal: Special Issue on English in Ukrainian Context, pp. 184 - 193. [in English]

Kovalevska, 2001 - Kovalevska T. Yu. (2001). Komunikatyvni aspekty neirolinhvistychnoho prohramuvannia : Monohrafiia [Communicative aspects of neurolinguistic programming: Monograph]. Odesa : Astroprynt, 344 p. [in Ukrainian]

Kravchenko \& Bondarenko, 2020 - Kravchenko N. O. \& Bondarenko K. A. (2020). Lingual Means of Imperative in the Lecture and Sermon Discourses. Arab World English Journal: Special Issue on English in Ukrainian Context. pp. 171 - 183. [in English]

Kutuza, 2018 - Kutuza N. V. (2018). Komunikatyvna suhestiia v reklamnomu dyskursi: psykholinhvistychnyi aspekt: monohrafiia [Communicative suggestion in advertising discourse: psycholinguistic aspect: monograph]. Kyiv : Vydachnychyi dim Dmytra Buraho, 736 p. [in Ukrainian]

Liubymov - Liubymov O. Triuizmy [Truisms]. [Electronic resource]. Access mode: https://nlp.trenings.ru/blog/71-tryuzmyi [in Russian] — Accessed: 25.11.2020.

Miller, 1998 - Miller, J. (1998). Magicheskoe chislo sem' plyus ili minus dva. O nekotorykh predelakh nashey sposobnosti pererabatyvat' informatsiyu [The magic number is seven plus or minus two. Some limits of our ability to process information]. The psychology of memory. Moscow: CheRo, pp. 564 - 582 [in Russian]

Nahimova, 2007 - Nahimova E. A. (2007). Pretsedentnye imena v massovoi kommunikatsii : monografiya [Case names in mass communication: monograph] Ekaterinburg : Institut social'nogo obrazovaniya, 207 p. [in Russian]

O’Connor \& Seymour, 1997 - O'Connor J. \& Seymour J. (1997). Vvedenie $v$ NLP [Introduction to NLP]. Chelyabinsk: Versiya, 256 p. [in Russian]

Pocheptsov, 1999 - Pocheptsov H. H. (1999). Teoriia komunikatsii [Communication theory]. Kyiv : VTs «Kyivskyi universytet», 308 p. [in Ukrainian]

Prisyazhniy - Prisyazhniy, S. Triuizmy (Metod kosvennogo vozdeystviya) [Truisms (Method of indirect influence)]. [Electronic resource]. Access mode: http://nlp.ee/t/1345trjuizmi [in Russian] — Accessed: 25.11.2020.

Semeniuk, 2010 - Semeniuk O. A. (2010). Osnovy teorii movnoi komunikatsii Navch. Posibnyk [Fundamentals of the theory of language communication Textbook. Manual]. Kyiv : VTs «Akademiia», 240 p. [in Ukrainian]

Serebrych, 2020 - Serebrych A. V. (2020). Pozytyvatsiia yak suhestiinyi chynnyk relihiinoho dyskursu. [Positivity as a suggestive factor of religious discourse]. Philological Treatises, $11(3-4)$, pp. $102-110$ [in Ukrainian]

Shevchenko, 2005 - Shevchenko I. S. (2005). Problemy typolohii dyskursu. Dyskurs yak kohnityvno-komunikatyvnyi fenomen / Pid zahaln. red. Shevchenko I. S.: Monohrafiia [Problems of discourse typology. Discourse as a cognitivecommunicative phenomenon / Ed. in Ch. Shevchenko I.S.: Monograph]. Kharkiv: Konstanta, pp. 233 - 236 [in Ukrainian]

Sheygal - Sheygal E. I. Inauguratsionnoe obrashchenie kak zhanr politicheskogo diskursa [Inaugural address as a genre of political discourse] [Electronic resource]. 
Access mode: http://www.philology.ru/linguistics1/sheygal-02.htm [in Russian] - Accessed: 25.11.2020.

Sheygal, 2014 - Sheygal E. I. (2004). Semiotika politicheskogo diskursa : monografiya [Semiotics of Political Discourse: Monograph]. Moscow : Gnozis, 326 p. [in Russian]

Slavova, 2012 - Slavova L. L. (2012). Movna osobystist lidera u dzerkali politychnoi linhvopersonolohii : SShA - Ukraina : monohrafiia [Linguistic personality of a leader in the mirror of political linguopersonology: USA - Ukraine: monograph]. Zhytomyr : Vyd-vo ZhDU im. I. Franka, 360 p. [in Ukrainian]

Sovremennye teorii diskursa, 2006 - Sovremennye teorii diskursa: mul'tidistsiplinarnyy analiz : sbornik / gl. nauch. red. O. F. Rusakova (2006). [Contemporary theories of discourse: multidisciplinary analysis: collection / ch. sc. ed. O. F. Rusakova]. Ekaterinburg: Diskurs-Pi, 209 p. [in Russian]

Received: 15 July, 2020 